\title{
Calcium and phosphorus requirements of the ewe during pregnancy and lactation
}

\author{
1. Calcium
}

\author{
BY G. D. BRAITHWAITE
}

National Institute for Research in Dairying, Shinfield, Reading, Berkshire RG2 9AT

(Received 4 February 1983 - Accepted 6 June 1983)

\begin{abstract}
1. Mineral balance and radioisotope studies have been carried out to test the adequacy of recent Agricultural Research Council (1980) recommendations for calcium and phosphorus for pregnant and lactating ewes. At the same time, $\mathrm{Ca}$ metabolism was compared throughout pregnancy and lactation in ewes restricted to these recommendations and in ewes given a plentiful supply of dietary $\mathrm{Ca}$ and $\mathbf{P}$.

2. Irrespective of their $\mathrm{Ca}$ intake, ewes were unable to absorb enough dietary $\mathrm{Ca}$ in late pregnancy and early lactation to meet the high demands, and skeletal stores of Ca were mobilized to make good the deficit.

3. Whereas ewes given the plentiful intake absorbed enough dietary $\mathrm{Ca}$ in mid- to late lactation to replace their lost skeletal $\mathrm{Ca}$ stores, ewes given the restricted $\mathrm{Ca}$ and $\mathrm{P}$ intake did not and, at the end of lactation, were still in deficit of about $10 \%$ of their total body $\mathrm{Ca}$.

4. Since $\mathrm{Ca}$ absorption in the restricted ewes occurred at the maximum efficiency $(66 \%)$ expected from a hay and concentrates diet, the Agricultural Research Council (1980) recommendations for Ca, particularly in midto late lactation, must be inadequate.

5. It is suggested that in calculating requirements, allowance must be made for the inevitable loss and subsequent replacement of skeletal stores.

6. The endogenous faecal loss of $\mathrm{Ca}$ was found to vary in direct relation to the food intake, and the significance of this finding to calculations of $\mathrm{Ca}$ requirements is discussed.
\end{abstract}

Recommendations of calcium and phosphorus requirements for sheep and cows at different stages of growth, pregnancy and lactation are published periodically by the Agricultural Research Council (ARC; 1965, 1980), the (US) National Research Council (NRC; 1968, 1975) and the Institut National de la Recherche Agronomique (INRA; 1978). These recommendations, which are based on all relevant research findings, vary considerably between the different sources, and indeed between successive publications from the same source.

For example, Table 1 shows the various recommendations of Ca requirements for a $50 \mathrm{~kg}$ sheep giving, on average, $1.361 \mathrm{milk} / \mathrm{d}$ during the first 8-10 weeks of lactation. Whereas the ARC (1980) recently reduced their recommended requirement from 10.0 to $4.3 \mathrm{~g} / \mathrm{d}$, the NRC (1975) increased their recommendation from 6.2 to $10.9 \mathrm{~g} / \mathrm{d}$. INRA (1978), meanwhile, recommend a value of $11.0 \mathrm{~g} / \mathrm{d}$.

The present work was carried out to test the adequacy of the recent ARC (1980) Ca and $P$ recommendations for pregnant and lactating ewes. At the same time, Ca and P metabolism was compared throughout pregnancy and lactation in ewes fed according to the ARC (1980) recommendations and in ewes given a plentiful supply of dietary Ca and $P$. The results of studies of $\mathrm{Ca}$ metabolism are presented in the present paper and those of $\mathrm{P}$ metabolism in the accompanying paper (Braithwaite, 1983). 
Table 1. Recommendations of calcium requirements $(\mathrm{g} / \mathrm{d})$ for a $50 \mathrm{~kg}$ ewe giving an average of $1.36 \mathrm{lmilk} / \mathrm{d}$ during the first $8-10$ weeks of lactation

\begin{tabular}{|c|c|c|c|c|c|}
\hline \multirow[t]{2}{*}{ Reference... } & \multicolumn{2}{|c|}{ ARC } & \multicolumn{2}{|c|}{ NRC } & \multirow{2}{*}{$\begin{array}{l}\text { INRA } \\
\text { (1978) }\end{array}$} \\
\hline & (1965) & (1980) & (1968) & (1975) & \\
\hline $\mathrm{Ca}$ recommendation & $10 \cdot 0$ & $4 \cdot 3$ & $6 \cdot 2$ & $10 \cdot 9$ & 11.0 \\
\hline
\end{tabular}

ARC, Agricultural Research Council; NRC, (US) National Research Council; INRA, Institut National de la Recherche Agronomique.

Table 2. Composition of the diet ( $\mathrm{g} / \mathrm{d}$ per $\mathrm{kg}$ body-weight) calculated to supply the calcium, phosphorus, energy and protein requirements recommended by the Agricultural Research Council (1980) for maintenance or for maintenance plus fetal or milk production

(Calculations based on a $50 \mathrm{~kg}$ ewe)

\begin{tabular}{|c|c|c|c|c|c|c|}
\hline \multirow[b]{2}{*}{ Ingredient } & \multirow[b]{2}{*}{ Maintenance } & \multirow{2}{*}{$\begin{array}{c}\text { Pregnancy } \\
(4-5 \text { months })\end{array}$} & \multicolumn{4}{|c|}{ Milk yield $(1 / d)$} \\
\hline & & & $2^{*}$ & $1 \cdot 5$ & 1 & 0.5 \\
\hline Hay & 7 & 15 & 27 & 21 & 17 & 12 \\
\hline Barley & 1 & 1 & 13 & 10 & 7 & 4 \\
\hline Maize & 4 & 4 & $8 \cdot 5$ & 7.4 & 6.25 & $5 \cdot 1$ \\
\hline Soya-bean & $1 \cdot 125$ & 3 & $4 \cdot 1$ & $3 \cdot 4$ & 2.6 & 1.9 \\
\hline
\end{tabular}

* Ewes were not able to consume all the large amount of food given.

\section{EXPERIMENTAL}

\section{Animals, housing and diet}

Twenty-six 3- to 4-year-old Suffolk ewes weighing $45-55 \mathrm{~kg}$ were used, half during 1980 and the other half during 1981. Six of the ewes acted as unmated controls and the remaining twenty were mated. At 2 months after mating, they were divided into two equal groups and housed in metabolism cages which allowed separate collection of urine and faeces. One group was given a diet of hay and concentrates, with added trace minerals and vitamins, calculated to supply the ARC (1980) recommended requirements for $\mathrm{Ca}, \mathrm{P}$, energy and protein (Table 2). This diet was adjusted at monthly intervals to meet the changing nutritional requirements of pregnancy and lactation. In early lactation, ewes were unable to eat all the large amount of food given. In practice, it was difficult to find a diet which provided these recommended energy and protein requirements but which did not have an excess of $\mathrm{Ca}$ and $\mathrm{P}$, and no supplementation with these minerals was needed even at peak lactation. The other group of ewes was given a diet of hay and concentrates, with added trace minerals and vitamins (Table 3 ), which provided a plentiful supply of nutrients (Ca, $P$, energy and protein). This diet was kept constant throughout pregnancy, was increased at parturition and kept constant at the higher level throughout lactation. Ewes had free access to distilled water.

All ewes were allowed to lamb normally. Lambs from ewes used in experiments in late pregnancy were killed immediately after birth and the placenta and fluids collected. Other lambs were removed from their mothers $2 \mathrm{~d}$ after birth and ewes were machine milked (Treacher, 1970) twice daily until the daily milk yield fell to $500 \mathrm{ml}$, and then once daily. 
Table 3. Composition of the diet ( $\mathrm{g} / \mathrm{d}$ per $\mathrm{kg}$ body-weight) calculated to provide a plentiful intake of calcium and phosphorus throughout pregnancy and lactation

(Calculations based on a $50 \mathrm{~kg}$ ewe)

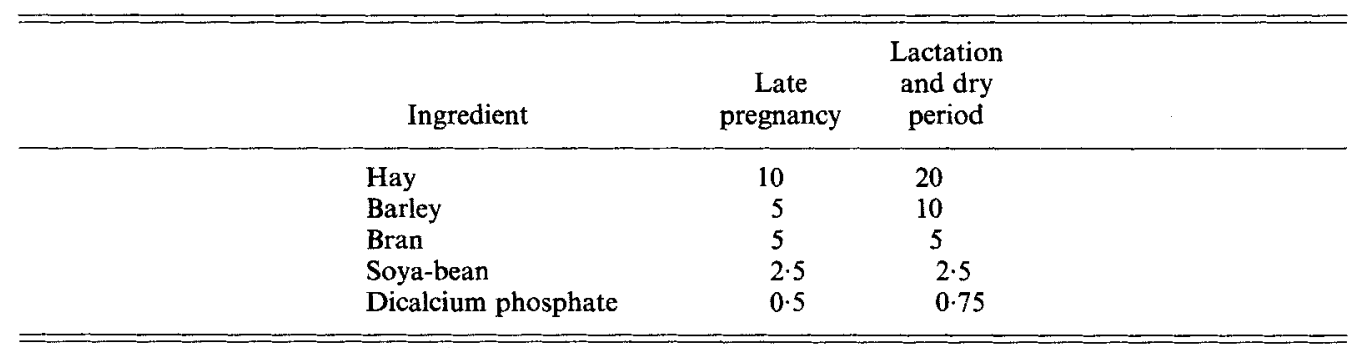

\section{Experimental procedure}

$\mathrm{Ca}$ and $\mathrm{P}$ kinetic studies were carried out in the six unmated ewes at the time of mating and in the twenty mated ewes at 130-137 d gestation, at 14-21, 42-49, 63-70, 94-99 d lactation and at 7-14 and 28-35 d post-lactation. Each of the mated ewes was used either two or three times; in late pregnancy-early lactation, in mid- to late lactation and during the post-lactation period.

A known amount of carrier-free ${ }^{45} \mathrm{Ca}$ as calcium chloride and ${ }^{32} \mathrm{P}$ as orthophosphate (Amersham International, Amersham, Bucks; 2.5 and $6 \mu \mathrm{Ci} / \mathrm{kg}$ body-weight respectively) in aqueous solution, was injected into a jugular vein and samples of blood, urine, faeces and milk were collected over a period of $7 \mathrm{~d}$ as previously described (Braithwaite et al. 1969). At the same time, $\mathrm{Ca}$ and $\mathrm{P}$ balance measurements were made.

\section{Methods}

The methods used for measurement of the Ca content of food, urine, faeces, fetuses and milk have been described previously (Braithwaite et al. 1969, 1970). Serum Ca was measured by the same procedure after precipitation of the protein with trichloroacetic acid (TCA; $1 \mathrm{ml}$ serum $+2 \mathrm{ml}$ TCA $(200 \mathrm{~g} / \mathrm{l}))$.

Radioactivity was measured in a Packard liquid-scintillation spectrophotometer (model 2450B) by a dual-label technique with external standardization. Samples of serum ( $1 \mathrm{ml}$ of TCA-supernatant fraction), urine $(1 \mathrm{ml}$ acidified with three drops $2 \mathrm{M}$-hydrochloric acid), milk $(0.5 \mathrm{ml}$ plus $0.5 \mathrm{ml} 2 \mathrm{M}-\mathrm{HCl})$ and ashed faeces and fetuses in $\mathrm{HCl}(1 \mathrm{ml})$ were counted in $10 \mathrm{ml}$ Insta-gel scintillator solution (Packard Instruments Co. Inc).

Kinetic analysis of the Ca results was done by the method of Aubert \& Milhaud (1960) modified for use with sheep (Braithwaite et al. 1969; Braithwaite \& Riazuddin, 1971; Braithwaite \& Glascock, 1976).

\section{RESULTS}

Mean values of the various processes of $\mathrm{Ca}$ metabolism at different stages of pregnancy and lactation are shown in Tables 4 and 5. Figs. 1-5 are composite curves plotted from these mean values. Although the curves are obtained from many different animals they do, nevertheless, show the variations in the more important processes over the whole reproductive cycle.

\section{Ca metabolism in ewes given a plentiful supply of dietary $C a$ and $P$}

Results of these studies are shown in Table 4 and Figs. 1-3. Demands for Ca (the sum of losses in the urine, endogenous faecal losses and losses to the fetus in pregnancy or the milk 


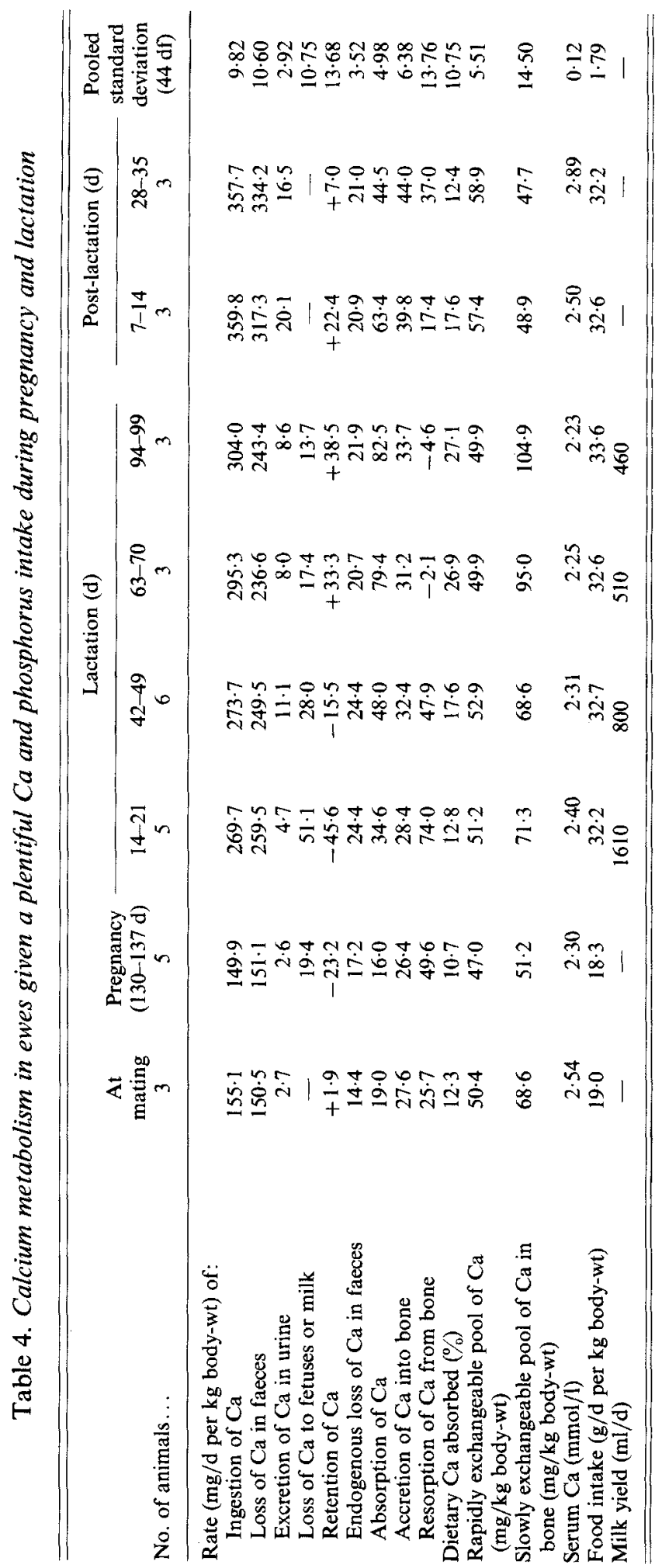




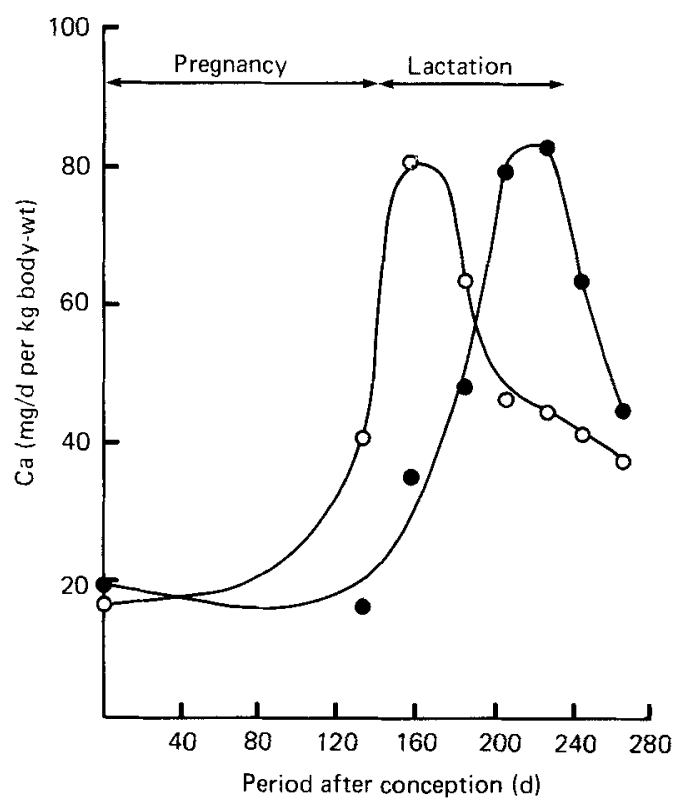

Fig. 1. Variations in calcium demands $(O)$ and in the rate of $\mathrm{Ca}$ absorption $(O)$ during pregnancy and lactation ( $\mathrm{mg} \mathrm{Ca} / \mathrm{d}$ per $\mathrm{kg}$ body-weight) in ewes given the plentiful dietary intake of $\mathrm{Ca}$ and phosphorus.

in lactation) increased markedly in late pregnancy (Fig. 1), reached a peak in early lactation and then decreased slowly throughout the remainder of lactation. These changes in demands were due mainly to changes in the rate of passage of $\mathrm{Ca}$ to the fetus in pregnancy and to the milk in lactation (Table 4). Urinary losses and endogenous faecal losses of Ca remained fairly constant, apart from a small rise in urinary loss post-lactation.

The amount of $\mathrm{Ca}$ absorbed from the intestine increased steadily during pregnancy to reach a peak in late lactation (Fig. 1) and then slowly declined. Despite the high dietary $\mathrm{Ca}$ intake, the increase in absorption was not sufficient to meet the high demands of late pregnancy and early lactation and it was only in mid-lactation, as demands for Ca fell and the rate of $\mathrm{Ca}$ absorption continued to rise, that there came a point when dietary $\mathrm{Ca}$ was absorbed in excess of demands. Since the dietary intake of $\mathrm{Ca}$ was high but constant throughout lactation, changes in the rate of absorption during this period were brought about by changes in the efficiency of absorption of dietary $\mathrm{Ca}$.

The deficit between $\mathrm{Ca}$ demands and absorbed dietary $\mathrm{Ca}$ in late pregnancy and early lactation was made good from skeletal reserves of $\mathrm{Ca}$; mobilization of these reserves was achieved by an increase in the rate of bone resorption relative to that of bone accretion, which remained fairly constant (Fig. 2). These skeletal reserves were then replenished in late lactation when $\mathrm{Ca}$ was absorbed in excess of demands. At this time bone resorption decreased to a low level relative to bone accretion, which increased slightly at this time.

Changes in these various quantities were reflected in the $\mathrm{Ca}$ balance of the ewes (Fig. 3). Retention was negative in late pregnancy and early lactation, when skeletal reserves of $\mathrm{Ca}$ were mobilized to meet the increase in demands. Retention then became positive in mid-lactation when dietary $\mathrm{Ca}$ was absorbed in excess of immediate requirements and enabled skeletal reserves to be replenished. Although the curves shown in Fig. 3 must only be an approximation, for reasons already discussed, graphical integration shows that ewes 


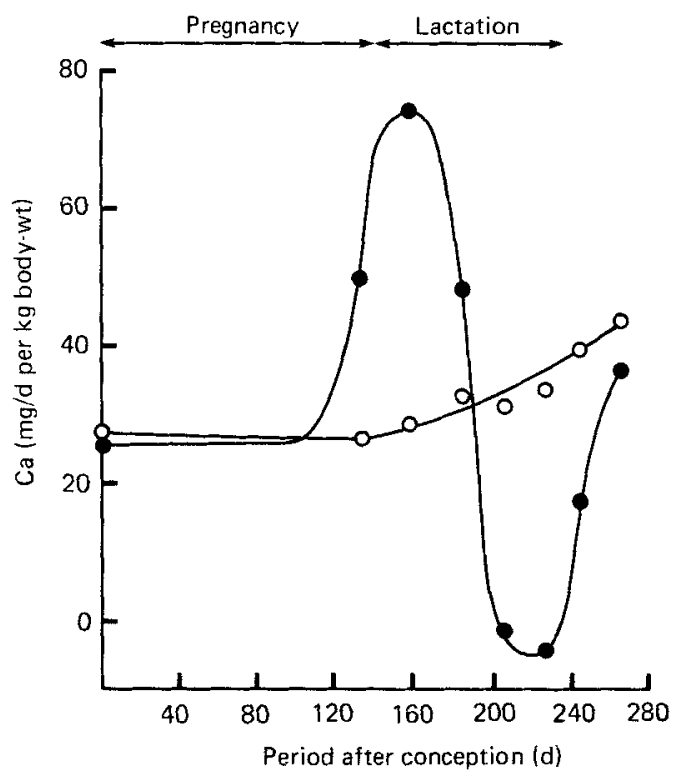

Fig. 2. Variations in the rate of accretion of calcium into bone $(\mathrm{O})$ and resorption of $\mathrm{Ca}$ from bone (O) during pregnancy and lactation $(\mathrm{mg} \mathrm{Ca} / \mathrm{d}$ per $\mathrm{kg}$ body-weight) in ewes given the plentiful dietary $\mathrm{Ca}$ and phosphorus intake.

lost approximately $110 \mathrm{~g}$, equivalent to about $20 \%$ of their total skeletal Ca during pregnancy and early lactation, and that this $\mathrm{Ca}$ was then virtually all replaced 1 month after the end of lactation.

Ca metabolism in ewes given a dietary $C a$ and $P$ intake restricted to the $A R C(1980)$ recommendations

Results of these studies are shown in Table 5 and Figs 3-5. Demands for Ca (the sum of losses in the urine, endogenous faecal losses and losses to the fetus or milk) increased in pregnancy to a peak in early lactation and then slowly decreased (Fig. 4). Maximum demands were slightly higher than in the ewes given the plentiful $\mathrm{Ca}$ and $\mathrm{P}$ intakes (Fig. 1).

The rate of absorption of Ca from the intestine also increased in pregnancy (Fig. 4), but the increase occurred slightly earlier than in ewes given the plentiful intake, and the maximum rate of absorption was lower. Absorption then decreased at an earlier stage of lactation. Not enough $\mathrm{Ca}$ was absorbed to meet the high demands of late pregnancy and early lactation, and although absorbed $\mathrm{Ca}$ did just exceed $\mathrm{Ca}$ demands in mid- to late lactation, it did not do so to the same extent as occurred in the plentiful-intake group of ewes.

Changes in the skeletal metabolism of ewes given the restricted dietary $\mathrm{Ca}$ and $\mathrm{P}$ intake are shown in Fig. 5. Skeletal reserves were mobilized in late pregnancy and early lactation, when the rate of bone resorption was increased relative to that of bone accretion. Reserves were then only partially replaced in mid- to late lactation, when the rate of bone resorption fell below that of accretion. This fall was not as great as occurred in ewes given the plentiful intake (Fig. 2).

For the sake of comparison, $\mathrm{Ca}$ balance measurements of ewes given the restricted and the plentiful dietary $\mathrm{Ca}$ and $\mathrm{P}$ intakes are shown in Fig. 3. The main difference between 


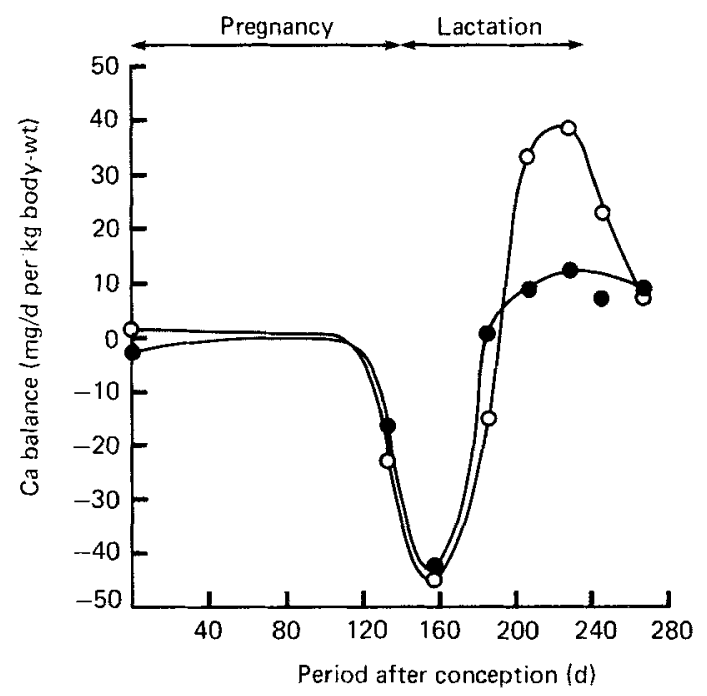

Fig. 3. Calcium balance (mg/d per $\mathrm{kg}$ body-weight) during pregnancy and lactation of ewes given the plentiful $\mathrm{Ca}$ and phosphorus intake $(\mathrm{O})$ and of ewes given the $\mathrm{Ca}$ and $\mathrm{P}$ intake restricted to Agricultural Research Council (1980) recommendations (O).

the two groups occurred in mid- to late lactation, when Ca retention in the restricted group failed to increase in the same manner as in the plentiful group. Integration of the balance curve shows that the restricted-intake group of ewes lost on average $92 \mathrm{~g} \mathrm{Ca}$ during pregnancy and early lactation (slightly less than the $110 \mathrm{~g}$ lost by the plentiful-intake group). At 1 month after the end of lactation, only about $37 \mathrm{~g}(40 \%)$ of this lost Ca had been replaced, compared with the plentiful-intake group, which had replaced virtually all their losses by this time.

Although the rate of absorption of $\mathrm{Ca}$ in mid- to late lactation in the restricted-intake group of ewes was lower than in the plentiful-intake group (Tables 4 and 5, Figs. 1 and 4$)$, the efficiency of absorption was much higher $(66 \%$ in the restricted-intake group; $22 \%$ in the plentiful-intake group) and remained at a high level throughout lactation and the following dry period.

Although the endogenous faecal loss of $\mathrm{Ca}$ increased during pregnancy to reach a peak in early lactation in the ewes given the plentiful $\mathrm{Ca}$ and $\mathrm{P}$ intake (Table 4), it then remained constant throughout the remainder of lactation and the following dry period. In contrast, endogenous faecal loss varied considerably in the restricted-intake group, having a low value in pregnancy, rising to a maximum value at peak lactation and then decreasing (Table 5). Regression analysis of the results from ewes of both the restricted-and plentiful-intake group showed that this variation was not related to $\mathrm{Ca}$ intake, neither was it related to the stage of lactation. It was, however, related to food intake (the sum total weight of food eaten), and Fig. 6 shows that there was a highly significant $(P<0.001)$ linear relationship $(r 0.83)$ between endogenous faecal $\mathrm{Ca}\left(\mathrm{V}_{f}\right)$ and food intake (FI), and the following regression equation was calculated:

$$
\mathrm{V}_{f}=3 \cdot 38+0 \cdot 572 \mathrm{FI} \text {, }
$$

where $\mathrm{V}_{f}$ is in $\mathrm{mg} / \mathrm{d}$ per $\mathrm{kg}$ body-weight and $\mathrm{FI}$ in $\mathrm{g} / \mathrm{d}$ per $\mathrm{kg}$ body-weight. 


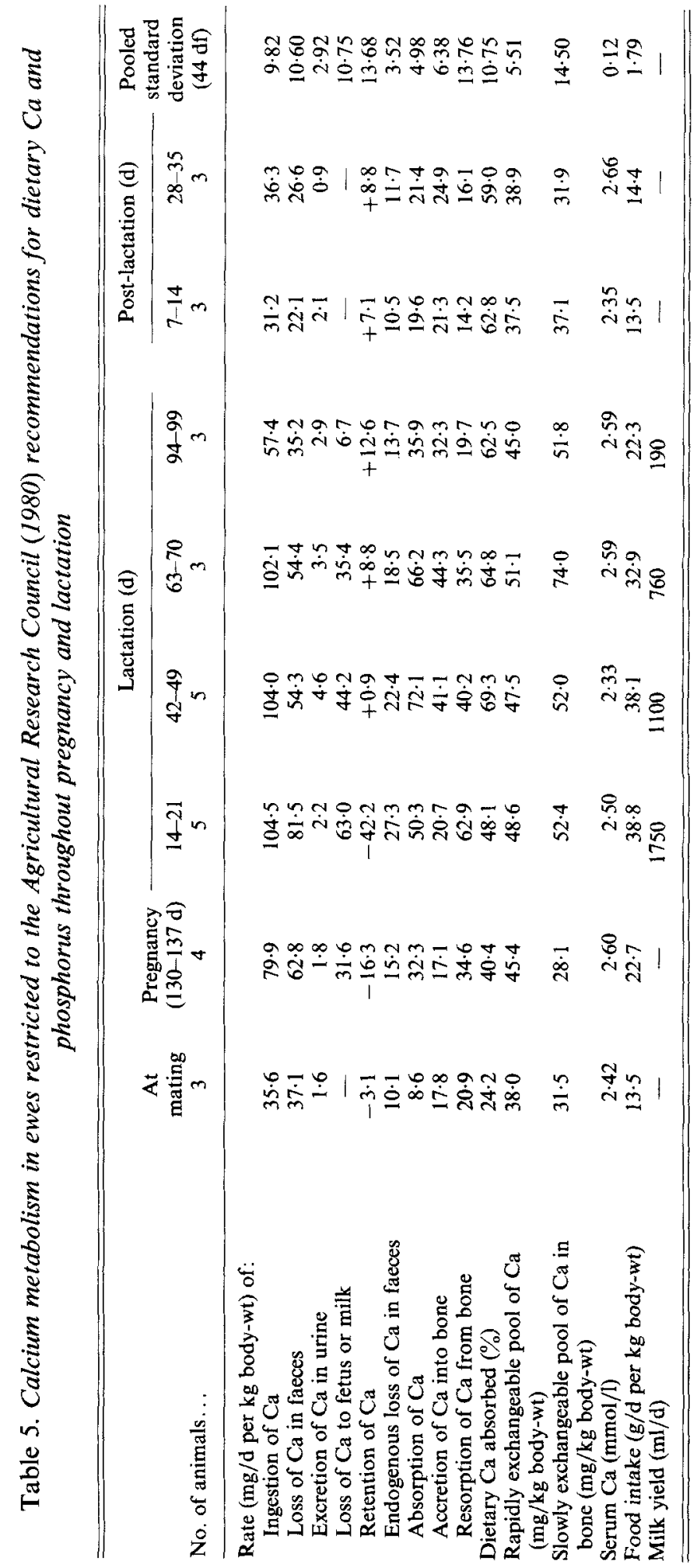




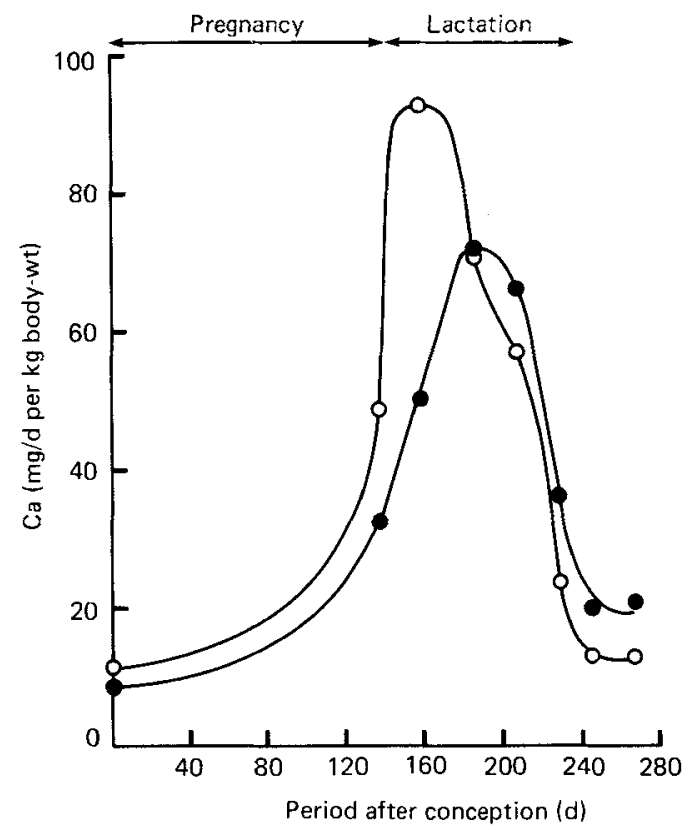

Fig. 4. Variations in calcium demands $(O)$ and in the rate of $\mathrm{Ca}$ absorption $(O)$ during pregnancy and lactation (mg/d per $\mathrm{kg}$ body-weight) in ewes given the $\mathrm{Ca}$ and phosphorus intake restricted to Agricultural Research Council (1980) recommendations.

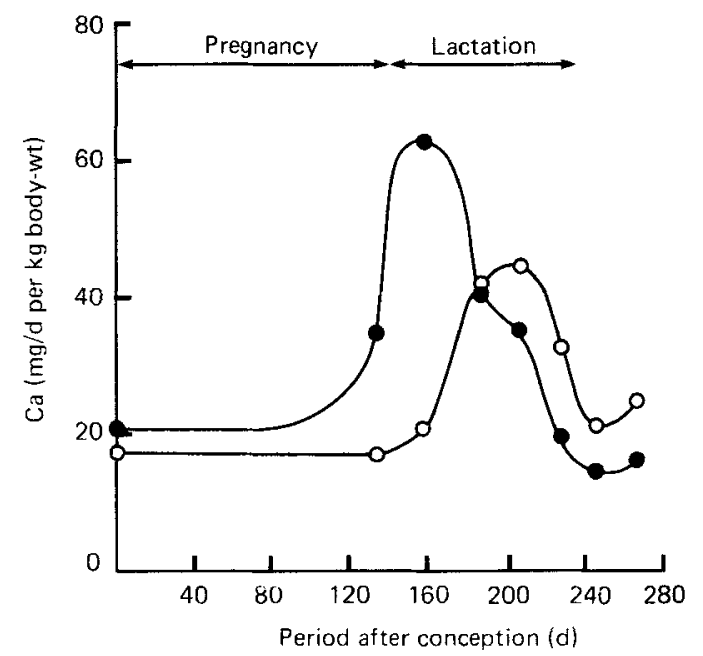

Fig. 5. Variations in the rate of accretion of calcium into bone $(\mathrm{O})$ and resorption of $\mathrm{Ca}$ from bone (O) during pregnancy and lactation $(\mathrm{mg} / \mathrm{d}$ per $\mathrm{kg}$ body-weight) in ewes given the $\mathrm{Ca}$ and phosphorus intake restricted to Agricultural Research Council (1980) recommendations. 


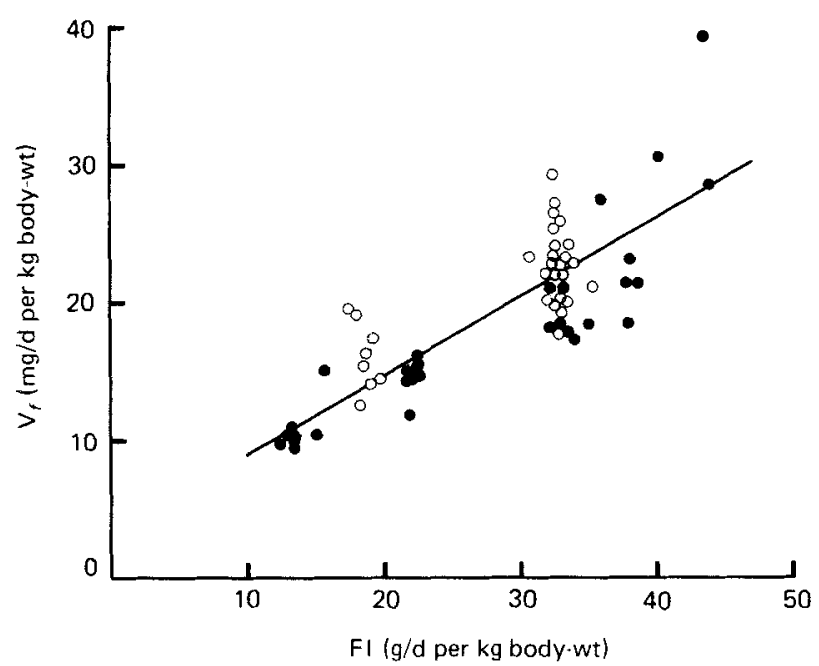

Fig. 6. Relationship between food intake (FI; g/d per $\mathrm{kg}$ body-weight) and endogenous faecal loss of $\mathrm{Ca}\left(\mathrm{V}_{f} ; \mathrm{mg} / \mathrm{d}\right.$ per $\mathrm{kg}$ body-weight $)$ in pregnant and lactating ewes. $\mathrm{V}_{f}=3.38+0.572 \mathrm{FI} . \mathrm{O}$, Ewes given the plentiful $\mathrm{Ca}$ and phosphorus intake; $\mathrm{O}$, ewes given the restricted $\mathrm{Ca}$ and $\mathrm{P}$ intake.

\section{DISCUSSION}

The present results confirm previous observations that ewes, despite a plentiful dietary intake of $\mathrm{Ca}$, are unable to absorb enough of this $\mathrm{Ca}$ during late pregnancy and early lactation to meet the increasingly high demands and have to mobilize skeletal mineral reserves (Braithwaite et al. 1969, 1970). These skeletal reserves are then replaced in midto late lactation, when $\mathrm{Ca}$ demands for milk production fall and $\mathrm{Ca}$ absorption increases to a high level.

Ewes restricted to the ARC (1980) mineral recommendation, like ewes given the plentiful mineral intake, mobilized skeletal reserves in late pregnancy and early lactation but, unlike the ewes given the plentiful intake, were unable to absorb sufficient dietary $\mathrm{Ca}$ to replenish these lost reserves in mid- to late lactation. At the end of lactation, these restricted-intake ewes were still in deficit of approximately $65 \mathrm{~g} \mathrm{Ca}$ (about $10 \%$ of their total body reserves). Although the $\mathrm{P}$ intake of these ewes was altered in parallel with the Ca intake and $\mathrm{P}$ demand altered in parallel with $\mathrm{Ca}$ demand (Braithwaite, 1983), it is unlikely that these changes in $\mathrm{P}$ supply or demand modified Ca metabolism in any way. Rather it is P metabolism that was probably modified in response to the changes in $\mathrm{Ca}$ supply and demand (Braithwaite, 1983).

The efficiency of absorption of dietary $\mathrm{Ca}$ was higher from the restricted $\mathrm{Ca}$ and $\mathrm{P}$ diet than from the plentiful diet throughout the whole of lactation. In fact its mean value in mid- to late lactation $(66 \%)$ was slightly higher than the $60 \%$ previously found from a low $\mathrm{Ca}$, hay and concentrates diet following stimulation of $\mathrm{Ca}$ absorption by treatment with 1- $\alpha$-hydroxycholecalciferol (Braithwaite, 1981) and only slightly lower than the $68 \%$ used by the ARC (1980) to calculate requirements. This suggests that all the available dietary Ca was being absorbed. Since ewes were still unable to replace their skeletal reserves in midto late lactation, the dietary intake of $\mathrm{Ca}$ at this time must have been inadequate.

Now the ARC, NRC and INRA all calculate $\mathrm{Ca}$ and $\mathbf{P}$ requirements by a factorial method. This assesses requirements in two stages. First, the net requirement is calculated from estimates of the storage and secretion of the element, made during growth, pregnancy 
or lactation, and of the obligatory endogenous losses from the body. Second, the dietary requirement is calculated by dividing the net requirement by a factor that represents the proportion of the dietary mineral available for absorption.

This method of calculating requirements is based on immediate day-to-day needs and makes no allowance for mobilization or replacement of skeletal reserves.

In their calculations, the ARC make the assumption that available dietary $\mathrm{Ca}$ is always absorbed with maximum efficiency $(68 \%)$ and that endogenous loss of $\mathrm{Ca}$ always occurs at the minimum rate $(16 \mathrm{mg} / \mathrm{d}$ per $\mathrm{kg}$ body-weight $)$. This means that their recommendations have no built-in safety factor. There is little chance, therefore, as shown by the present results, of animals fed strictly according to these recommendations being able to replace in mid- to late lactation those inevitable losses of skeletal reserves that occur in late pregnancy and early lactation.

The present results suggest that, rather than feed pregnant and lactating animals according to immediate day-to-day needs, it would be better to give less mineral than is indicated from calculated requirements during late pregnancy when, because of the limitation on absorption, requirements cannot be met from the diet alone and some mobilization of reserves is necessary; and to give more mineral in mid- to late lactation when absorption is high and animals need to replenish skeletal reserves. In other words, an allowance must be made in the recommendations for the inevitable loss and subsequent replacement of skeletal reserves.

Since ewes can respond to periods of Ca deficiency by increasing absorption to a high level when $\mathrm{Ca}$ is again plentiful (Braithwaite, 1974, 1978), ewes fed continuously according to ARC (1980) recommendations for $\mathrm{Ca}$ throughout several reproductive cycles would probably respond to the losses of skeletal reserves accrued during the first reproductive cycle by increasing absorption to a maximum during the whole of the subsequent cycles. In spite of this situation, which is probably highly undesirable, ewes would still be unable to absorb enough dietary $\mathrm{Ca}$ to meet the demands of pregnancy and lactation, even assuming the efficiency of absorption remains constant at $66 \%$ (the mean maximum value observed in the present study). This is because actual endogenous losses of $\mathrm{Ca}$ are higher than those predicted by the ARC in their calculation of requirements (see above). The long-term effect of feeding according to the ARC (1980) recommendations for $\mathrm{Ca}$, therefore, would be a progressive demineralization of the skeleton.

It is well known that the endogenous faecal loss of $\mathrm{Ca}$ is unaffected by $\mathrm{Ca}$ intake, and the reason for high values reported by various workers (see Braithwaite, 1982) has remained obscure. Although it was recognized that the observed changes in faecal endogenous loss of $\mathrm{Ca}$ in the present study may have been due to factors other than food intake, the significant relationship between this loss and food intake, which was observed in both groups of ewes, was of such great interest that it prompted a re-examination of all the previous studies carried out at the National Institute for Research in Dairying. The results, which have already been published (Braithwaite, 1982) confirmed a highly significant linear relationship, endogenous faecal loss increasing by about $0.64 \mathrm{mg} / \mathrm{d}$ per kg body-weight for each $1 \mathrm{~g} / \mathrm{d}$ per $\mathrm{kg}$ body-weight increase in food intake. In their calculation of $\mathrm{Ca}$ requirements, the ARC (1980) make the assumption that total endogenous loss of Ca (urinary loss plus endogenous faecal loss) remains constant at $16 \mathrm{mg} / \mathrm{d}$ per $\mathrm{kg}$ body-weight irrespective of age of physiological state. This assumption results in a considerable underestimation of requirements during periods of high food-intake. Although this underestimation probably does not matter in early lactation when, as already discussed, absorption of $\mathrm{Ca}$ appears to be limited and ewes, irrespective of their intake, cannot absorb enough dietary $\mathrm{Ca}$ to meet their needs, it would be important in mid- to late lactation and could be be another contributory factor to the inability of ewes to replenish previously lost reserves. As already suggested (Braithwaite, 1982), a variable factor for endogenous Ca loss 
should be introduced into the rationing scheme which is based on some measure of level of feeding.

Although the rate of absorption of $\mathrm{Ca}$ did not rise to as high a level in the restricted-intake group of sheep as it did in the sheep given the plentiful intake, it did increase at an earlier stage in the reproductive cycle. The reason for this is at present unclear. Previous studies have suggested that active absorption of $\mathrm{Ca}$ is stimulated only when losses of skeletal reserves have taken place (Braithwaite et al. 1969, 1970; Braithwaite, 1974, 1978). In the present study there was little difference between the two groups either in the rate or in the amount of loss of skeletal reserves during pregnancy.

In conclusion, the present work shows that the ARC (1980) recommendations for dietary $\mathrm{Ca}$ in mid- to late lactation do not allow the replacement of those skeletal reserves of $\mathrm{Ca}$ mobilized in late pregnancy and peak lactation. These recommendations are therefore inadequate.

The author thanks Miss K. E. Masters, Miss F. J. McEwan and Mr J. K. Tweed for skilled technical assistance, Mr S. V. Morant for statistical advice and Mr A. Mowlem for supervising the care of the experimental animals.

\section{REFEREN CES}

Agricultural Research Council (1965). The Nutrient Requirements of Farm Livestock, No. 2, Ruminants. London: H.M. Stationery Office.

Agricultural Research Council (1980). The Nutrient Requirements of Ruminant Livestock. Slough: Commonwealth Agricultural Bureaux.

Aubert, J. P. \& Milhaud, G. (1960). Biochimica et Biophysica Acta 39, 122-139.

Braithwaite, G. D. (1974). British Journal of Nutrition 31, 319-331.

Braithwaite, G. D. (1978). British Journal of Nutrition 39, 213-218.

Braithwaite, G. D. (1981). Journal of Agricultural Science, Cambridge 96, 291-299.

Braithwaite, G. D. (1982). Journal of Agricultural Science, Cambridge 99, 355-358.

Braithwaite, G. D. (1983). British Journal of Nutrition 50, 723-736.

Braithwaite, G. D. \& Glascock, R. F. (1976). Biennial Reviews, National Institute for Research in Dairying pp. 43-59.

Braithwaite, G. D., Glascock, R. F. \& Riazuddin, Sh. (1969). British Journal of Nutrition 23, 827-834.

Braithwaite, G. D., Glascock, R. F. \& Riazuddin, Sh. (1970). British Journal of Nutrition 24, 661-670.

Braithwaite, G. D. \& Riazuddin, Sh. (1971). British Journal of Nutrition 26, 21 5-225.

Institut National de la Recherche Agronomique (1978). Alimentation des Ruminants. Versailles: INRA Publications.

National Research Council (1968). Nutrient Requirements of Domestic Animals, No. 5, Nutrient Requirements of Sheep. Publication no. 1693. Washington, DC: National Academy of Sciences.

National Research Council (1975). Nutrient Requirements of Sheep, 5th ed. Washington, DC: National Academy of Sciences.

Treacher, T. T. (1970). Journal of Dairy Research 37, 289-295. 